\title{
Dušan Tellinger
}

(Košice, Szlovákia)

\section{OROSZ-MAGYAR VONATKOZÁSOK A POPOVIČ-FÉLE FORDÍTÁSELMÉLETBEN}

\begin{abstract}
In the background of Anton Popovič's research is multiculturalism, enabling him to move from culture to culture. A. Popovič's approach was interdisciplinary and his understanding of culture still provides ideas for contemporary translation studies. His fundamental book from 1975 is based on his stylistic approach to equivalence according to which the translator has to recode the cultural and stylistic values of the source text into equivalent cultural and stylistic target text. The comparison of Russian texts with their Hungarian translations demonstrate A. Popovič's conviction that equivalence, above all stylistic equivalence, is the ideal method when the translator has to deal with cultural lexicon, especially with realia.
\end{abstract}

Keywords: cultural background, multiculturalism, interdisciplinary research, so-called realia, stylistic competence, stylistic equivalence

\section{Bevezetés}

Ukrán-magyar származásának köszönhetően az eperjesi születésű és a család homonnai kötődésével rendelkező Anton Popovič nagy teret szentelhetett a magyar nyelvre átültetett orosz szépirodalmi alkotásoknak is, amikor a stilisztikai ekvivalencia elméletét kívánta különböző nyelvekből és történelmi időszakokból vett példákkal alátámasztani. Azt a törekvést vizsgálta, amikor a fordító igyekszik elérni a jelentések invariáns egyezését és kifejezésbeli azonosságát, ami csak az eredeti mü elemeinek funkcionális egyenértéküsége feltételének betartásával valósulhat meg a fordításban. Ez volt A. Popovič számára a legmegbízhatóbb alap, amely egy tudós számára fogódzót nyújt a fordítások történelmi értékeinek megállapításához is. A fordítások stilisztikai kutatását tehát történelmi összehasonlítás alapján végezte, amely során legismertebb könyvében arra is találunk példákat, hogy magyar fordításokat hasonlít össze eredeti orosz müvekkel. A korszaknyitó Müforditás elmélete: A szöveg és az irodalmi metakommunikáció szempontjai (1975) címü müvében már teljes mértékben kibontakozott a kultúrák közötti kapcsolatok fontossága az akkortájt végleges alakba formálódó, tudományosan megalapozott és megfogalmazott elméletében, amely a következő három évtizedben, korai halála után is tovább fejlődött - nagymértékben tanítványainak köszönhetően föleg Nyitrán és Pozsonyban, de Eperjesen is. Ha példákhoz nyúlt ebben a könyvében a szerző, legnagyobb részt az orosz müveket hasonlította össze szlovák, cseh, angol és néhány esetben magyar fordításokból merített anyaggal is. Ez Popovič számára a fordítások stilisztikai tanulmányozásához nyújtott anyagot, melyek alapján lehetséges volt konkrétan annak vizsgálata, hogy 
vajon hozzájárult-e bármelyik fordítás a múltban egy bizonyos közegben új stílus megteremtéséhez egy adott társadalmi helyzetben. Ékes példái ennek IlfPetrov két máig ismert szatírája, a Tizenkét szék és az Aranyborjú kiadásai a Nyugatnál Gellért Hugó fordításában, amelyet megelözött a Szinetár-Gyurkó alkotópáros Aranyborjú átültetése az akkori magyar viszonyok közé. A Horthyrendszer vége felé az Aranyborjúnak már egy újabb fordítása készült el a Garcsenko-Kristóf fordítópárosnak köszönhetően, amelynek címe, A szovjet milliomos 1943-ban vagy 1944-ben üzleti szempontból volt vonzó. A szocialista Kádár-korszak kezdetén, 1957-ben egy újabb Aranyborjú fordítás jelent meg a Fóthy-Wessely híres fordítópáros közremüködésével.

\section{Kultúrák közötti kapcsolatok orosz-magyar vonatkozásban}

Az említett könyv egyik legfontosabb fejezetében Popovič tizenkét oldalon keresztül (vö. Popovič 1975: 186-197 és 1980: 204-214) a kultúrák közötti kapcsolatok fontosságát a fordítási müveletekben igyekezett példákkal illusztrálni az akkortájt avantgárd jellegü orosz költészet képviselője, Andrej Andrejevics Voznyeszenszkij Rubljovszkoje sossze címü verse alapján. Voznyeszenszkij költészetének Popovič által végzett elemzése a reáliák megörzése vagy adaptációja, esetleg kihagyása szempontjából is érdekes, hiszen a könyvben a szerző e rövid költeménynek nemcsak nyelvi és költői felépítésére fordít nagy figyelmet, hanem fóképpen a fordítások stilisztikai pontosságára és a térközi tényezőkből fakadó kulturális különbségek konfrontációjára is, amelyek az angol, a magyar, a cseh és a szlovák fordításban figyelhetők meg. 1964-ben az Európa Könyvkiadó megjelentetett egy 147-oldalas Voznyeszenszkij-válogatást Fémszirén címmel. A költeményeket Pór Judit válogatta és Elfer István, Fodor András, Garai Gábor, Illyés Gyula, Rab Zsuzsa, Somlyó György és Weöres Sándor fordította.

Hogy vajon miért is nyúlt Popovič $(1933$ - 1984) az ugyanahhoz a generációhoz tartozó Voznyeszenszkij (1933 - 2010) költeménye különböző stilisztikai kidolgozásához mint alappéldákhoz felejthetetlen múvének már említett fejezetében, amely 2006-tól az orosz (1980) és a magyar (1980) nyelven kívül már olaszul is olvasható, az könnyen kivehető az adott fejezet (A müfordítás szemiotikai kérdései) bevezető szavaiból. A térbeli, időbeli és kultúrák közötti dimenzió fontossága a két különböző kultúra összevetésénél annyira meghatározza a fordítás jellegét, ahogyan azt a következő szövegek összehasonlítása is mutatja az orosz és magyar kultúra példáján:

Рублевское шоссе

Мимо санатория

Реют мотороллеры.

За рулем влюбленные -

Как ангелы рублевские.
Rubljovo felé

A szanatórium alatt robogók villámlanak.

Csupa szerelmes vezet rubljovi angyalok ezek?! 
Фреской Благовещения,

Резкой белизной

За ними блещут женщины,

Как крылья за спиной!

Их одежда плещет,

Рвется от руля,

Вонзайтесь в мои плечи,

Белые крылья.

Улечу ли?

Кану ль?

Соколом ли?

Камнем?

Осень. Небеса.

Красные леса.
Freskón annunciáció:

hófehér a lány

hátuk mögött, és oly villogó

válluknál, mint a szárny!

Ruhájuk a szélben

röpdös, lengve száll;

vállamra fehéren

íly szárny nőne bár!

Szállni hajt majd?

Mélybe vet?

Mintha karvalyt?

Mint követ?

Ösz van. Tárt egek.

Rőt rengetegek.

Az orosz történelmi kolorit megőrzése inkább háttérbe szorult Garai Gábor (1929 - 1987) fordításában annak érdekében, hogy a cselekményt közelebb hozza a korabeli magyar olvasóhoz. Ezt a fordítói szándékot Popovič már önmagában az orosz költemény címe megváltoztatásával a Garai-fordításban is bizonyítja, amelyben egy fontos reália került kihagyásra. Az orosz költő a vers címében szándékosan összevetett két kultúrát: a középkori 14. és 15. századi egyházi orosz kultúrát, amely Andrej Rubljov, a moszkvai iskolához tartozó festő nevéhez kötődik, a modern orosz kultúrával, amelyet a szanatórium megemlítése mellett pedig éppen a Rubljovo felé vezetö müút (sossze) jelenti, és ez az eredeti szövegben párosul még a motorroller (robogó) és rulj (volán) szavakkal is. Az orosz sossze pl. Anselm Paul Alexis Hollo (1934 - 2013) finn költő és fordító angol átültetésében highroad (országút), éppen úgy, mint Václav Daněk (1929 - 2008) cseh fordításában is - silnice, Miroslav Válek (1927 - 1991) szlovák fordításában egyszerüen csak út - cesta. Az akkori időkben éppen annyira kifejezően a robogók jelentették a fiatalság modern életmódjának szimbólumát, míg a jelenkorban a maroktelefonok azok, elég csak visszaemlékezni az 1962-es Mamma Roma címü filmre, amelyben Pier Paolo Pasolini szemlélete szerint a robogók a fiatalság lelki és testi pusztulásának szimbólumai is egyúttal. A robogók tehát a fiatalok életstílusát jelképezték Keleten is, Nyugaton is 50 évvel ezelött az 1961-ben kezdődő gazdasági lendület - „gazdasági csoda” idején. Érdekesség még, hogy a magyar, angol, cseh és szlovák fordítás is ugyanabban az évben, 1964-ben jelent meg, tehát két évvel később a Háromszögü körte (oroszul Treugol'naja gruša) a hruscsovi olvadás tetőfokán lehetővé vált moszkvai kiadása után, 
amelyben az elemzett költemény is megtalálható csaknem harminc más Voznyeszenszkij-alkotással együtt.

A modern kort tehát az analizált versben az automobilizmus vívmányai jelentik, amelyet az eredetiben a sossze mellett még két reália is képvisel, de Garai Gábor a versben szó szerint csak egyet őrzött meg belölük (motorollery robogók). A rulj reáliát, amelyet kétszer is megismételt Voznyeszenszkij a költeményében, csak körülírva találhatjuk meg egyszer a Garai-fordításban: csupa szerelmes vezet. Ahogyan ez a lényeges változás is mutatja: „a fordító itt a 'motorkerékpáros szerelmesek' mozgását örökítette meg, $\mathrm{s}$ a hangsúly nem a rubljovi ikon világával való szembesítésen van, hanem a jelenség puszta leírásán. Ez a jelentés eltolódás meghatározza a szöveg további részeinek olvasatát, olvasói 'generálását' is“ (Popovič 1980: 211). Ez Popovič szerint a polivalencia csökkenését jelenti, amely a kifejezések konkrétságának veszteségével magyarázható. A robogókon száguldozó szerelmesek akkori modern világa nincs szembesítve a magyar fordításban a bizánci-pravoszláv vallásra utaló Rubljov annunciációt ábrázoló képe középkori világával. Popovič ennek a Voznyeszenszkij költeményének a magyar fordításában a kifejezések irracionalitásának csökkenését látta.

\section{A fordítás stilisztikai értéke}

Popovič szerint az ekvivalencia típusok ranglétrájának legmagasabb fokán éppen a stílusekvivalencia áll, ami miatt egyesek kritizálták is az elmélete praktikus érvényességét (vö. Tellinger 2012: 123). Ez a kritika elsősorban a költészet fordítására ráerőltetett Popovič-i állítást célozta meg, ugyanis a stílusaspektust nem lehet fölé helyezni a prózához hasonlóan a költészetben is a fordítás többi aspektusai alárendeltsége árán. Hogy milyen nagy jelentőséget szentelt Popovič a kifejezésbeli vagy stílusekvivalenciának, az kivehető már önmagában annak a fejezetnek a címéből is (A kommunikáció a müfordítás stílusában), melyben a könyvének talán a legfontosabb orosz-magyar vonatkozása található: Ilf-Petrov az Aranyborjú háború előtti, háború közepette és háború utáni magyar fordításairól lenne itt szó, hiába Popovič könyvében nincs megemlítve az a tény, milyen gazdag és bonyolult elözményei voltak a vesztes háború második felében megjelenő Ilf-Petrov Aranyborjú címü kalandregénye magyar fordításának. Nem említi például azt a tényt sem, hogy a 30-as évek fordítása után egy újabb szándék állt elő még a Szovjetunió ellen indított háború előtti utolsó időszakban. Ismeretes, hogy 1941 tavaszán Moszkvában Rátz Kálmán kinyilvánította azt a tervét (1888 - 1951) Kristóffy József moszkvai követnek, hogy szeretné magyarra fordítani a következő címek alatt Ilja Ilf és Jevgenyij Petrov szatirikus müveit: Tizenkét szék (Dvenadcaty sztuljev) és Aranyborjú (Zolotoj tyeljonok). Ezeket az előzményeket mellőzve Popovič könyvében már csak a háborús magyar szovjet politika légkörében megvalósult Ljev Petrovics Garcsenko és Kristóf Béla fordításáról van szó, amely évszám nélkül jelent meg Budapesten a Hungária Könyvkiadónál az akkori olvasókat vonzó, A szovjet milliomos cím alatt, 
amelyben nyoma sincs a sztálini szovjet propagandának. Popovič 1944-re teszi a fordítás megjelenését könyvében, de más források szerint már 1943-ban kiadta a Hungária Ilf-Petrov nagy regényét - amellett a 44-es év is egy törésvonalat jelentene: hisz más lehetett volna a könyv fogadtatása még az év első két és fél hónapjában a német megszállás előtt, mint aztán a későbbi hónapok zürzavarában, a fokozódó háborús szovjetellenes hangulat eszkalációjában.

Popovič szerint akkortájt a könyv nem járult hozzá a magyar sajtó visszhangja szerint a szovjet rendszer teljes diszkreditálásához a fordítók részéről. De nem állhatott a fordítás és a fordítói szándék sem ellentétben a magyar társadalom kultúrpolitikai körülményeivel és a kulturális-társadalmi helyzettel. Már önmagában az eredeti cím megváltoztatása is sokatmondó a fordításban. Popovič úgy ítéli meg a címváltoztatást, hogy a fordítók ezzel a két ellentétes reáliával (szovjet és milliomos) utalni akartak a szovjet rendszer paradoxonjaira, amikor ezt a két társadalmilag ellentétes reáliát kapcsolták össze. Ennek az oximoronnak használatával reklámot is akartak csinálni a fordítók a könyvnek abban a hitben, hogy a szatíra a szovjet rendszer gyenge pontja volt a sztálinizmus éveiben. De Popovič egyúttal aláhúzza azt a tényt is, hogy még ilyen módon sem tudtak a fordítók az akkori vérzivataros időkben populáris olvasmányt csinálni Ilf-Petrov szatírájából, mert a magyar olvasónak még hiányzott a személyes tapasztalata a szocializmus megvalósításának félresikerült kísérletéről Magyarországon Rákosi alatt. Ez vonatkozik Gellért Hugó (1889 - 1937) Tizenkét szék és Szinetár-Gyurkó Aranyborjú átültetéseire is a 30-as években. Csak Fóthy János (1899 - 1979) és Wessely László (1904 1978) Aranyborjú fordításának köszönhetően, amelyet először 1957-ben adott ki az Európa Könyvkiadó, sikerült az, hogy a már közismert mü Osztap Bender alakjával, a nagy kombinátorral, halhatatlanná vált a mai napig, habár csak azok számára, akik még ismerik.

\section{Stilisztikai jellegzetességek a két magyar Ilf-Petrov Aranyborjú fordításában}

A fordítói stratégiák Popovič szerint jól kivehetők azokból a stílusmódosulásokból, amelyek bekövetkeztek az Aranyborjú két különböző korszakban történt magyar fordításában. Az Aranyborjúból vett szemelvényben, amely Popovič könyvében található, komplex módon jelennek meg stilisztikai, nyelvi és tematikai szempontok. Míg az 1943-44-es háborús évben kiadott fordításban nem sikerült átmenteni a mü mély struktúráját a célnyelvbe, addig az jelesre sikerült a szocializmus keserü tapasztalataival rendelkező fordítóknak 1957-ben. A nyelvi kifejezőeszközöket szemlélteti Popovič a következő szemelvénnyel (Торжественный комплект - Ünпері szókészlet) a 43-44-es és az 57-es fordításból, amelyet mint példát idézünk. Ezek is mutatják, milyen siker lehetett a második fordítás és milyen könnyen kerülhetett be a szöveg mondandója az olvasók tudatába és nyelvébe. 


\section{Торжественный комплект}

Незаменимое пособие для сочинения юбилейных статей, табельных фельетонов, а также парадных стихотворений, од и тропарей

Раздел 1. Словарь

Существительные
1. Клики
11. Ошибки
2. Трудящиеся
12. Стяг (флаг)
3. Заря
13. Ваал
4. Жизнь
14. Молох
5. Маяк
15. Прислужник
6. Чac
16. Скок
7. Враг
17. Конь
8. Поступь
18. Сердце
9. Вал
19. Прошлое

10. Пески

Прилагательные

1. Империалистический

2. Капиталистический

3. Исторический

4. Последний

5. Индустриальный

6. Стальной

7. Железный

Глаголы

1. Пылать

2. Взметать(ся)

6. Вершить(ся)

3. Выявлять

7. Петь

4. Рдеть

8. Клеветать

5. Взвивать(ся)

9. Скрежетать

10. Грозить

Художеств. эпитеты

1. Злобный

2. Зубовный

Прочие части речи

1. Девятый

4. Пускай!

2. Двенадцатый

3. Пусть!

5. Вперед!

\section{Ünnepélyes szókészlet}

Nélkülözhetetlen segédeszközök jubileumi cikkek, ünnepi tárcák stb., valamint alkalmi költemények, ódák és dithyrambusok fogalmazására. 
Főnevek:

1. dolgozók

2. Baál

3. ellenség

4. zászló (lobogó)

5. szív

6. tévedések

7. ujjongás

8. élet

9. mécs

10. Moloch

11. ércparipa

12. bérenc

13. ugrás

14. por

15. óra

16. tett

17. múlt

18. hullám

19. fog

20. ipar (iparosodás)

Mủvészi jelzők:

1. acsarkodó

2. fürészfogú
Melléknevek:

1. új

2. történelmi

3. imperialisztikus

4. kapitalista

5. végső

6. acélos

7. (fel)lángol

Igék:

1. tovarobog

2. felzúg

3. (el)söpör

4. lobog

5. leng

6. vicsorog

7. (arcul) üt

8. dalol

9. beteljesít

10. rágalmaz

Egyéb beszédrészek:

1. kilencedik

2. tizenkettedik

3. úgy legyen!

4. legyen úgy

5. előre

\section{Ünnepi szókészlet}

Pótolhatatlan segédeszköz jubileumi megemlékezések, ünnepi vezércikkek, valamint díszköltemények, ódák és zsoltárok írásához

\section{Fejezet: Szótár}

\section{Főnevek}
1. Csatakiáltás
2. Dolgozók
3. Hajnal
4. Élet
5. Világítótorony
6. Hibák
7. Hiányosságok
8. Zászló (Lobogó)

10. Moloch

11. Bérenc

12. Perspektíva

13. Ellenség

14. Láncszem

15. Lendület

16. Paripa

17. Szív 
9. Baál

1. Imperialista

2. Kapitalista

3. Történelmi

1. Lángolni

2. Elsöpörni

3. Virulni

4. Felkavarni

5. Lobogni (Lengeni)

6. Betetőzni

1. Dühödt

1. Tizenkettedik

2. Hadd!
18. Múlt

19. Fáklya

Melléknevek
4. Ipari
5. Töretlen
6. Acélos
7. Elsöprö

Igék:

7. Dalolni

8. Rágalmazni

9. Csikorgatni (Vicsorgatni)

10. Fenyegetni

11. Csaholni

Művészi jelzők:

2. acsarkodó

Egyéb beszédrészek:

3. Csak rajta!

4. Elöre!

Az újabb magyar fordításban Popovič megfigyelte azt a hatást, amelyet már az új rendszer gyakorolt a magyar szókincsre, így aztán stilisztikailag a fordítás jobban megfelelt az eredetinek, mint szemantikailag. A magyar mozgalmi úzusnak megfelelően dolgozta át a fordítópáros a sematizmus jegyében íródott „szótárt“, amivel az eredeti münek nagy szolgálatot tett. Ez egy igazi előrelépést jelentett a háború időszakában keletkezett szöveggel szemben, amely az olvasót még felkészületlenül érte, hisz nem volt tapasztalata a sematikus művészi alkotásokkal sem az irodalomban, sem a festészetben, sem a filmmüvészetben. A regény szatirikus elemeinek megértéséhez még nem voltak adottak a feltételek a magyar társadalomban 1943-44 tájt.

\section{A. Popovič fordításelméletének magyar fogadtatása}

Hála Zsilka Tibor fordításának, Popovič fordításelmélete magyar szakértők körében ismertebb lett, mint máshol Kelet-Közép-Európában, mert még az 1980-as orosz fordításnak sem volt olyan lelkes fogadtatása, mint éppen a magyar változatnak, és valószínüleg a könyv keletkezési ideje miatt a 2006os olasz fordításnak sincs olyan hatása manapság, mint Zsilka átültetésének. Legtöbbször a magyar szakirodalomban azok a gondolatok vannak kiragadva az 1980-ban magyar nyelven megjelent müből, amelyek az elemi fordítói fogalmak magyarázatát adják a mai magyar fordítói szakirodalom olvasója számára is. Jankovics Mária az orosz-magyar vonatkozásokról szóló 
fordításelméleti könyvében föképpen e könyvnek az egyenértéküség megteremtését tárgyaló részében látja Popovič fontos útmutatásait: „Minden fordításnak, így a müfordításnak is a legfőbb gondja az egyenértéküség megteremtése, vagyis az, hogy a fordítás újrateremtse a müalkotást egy másik nyelv anyagából úgy, hogy a másfajta élményhátterü olvasók is megérthessék az író eredeti üzeneteit és rejtett jelzéseit" (Jankovics 2011: 148).

Klaudy Kinga közismert, angol nyelven megjelent könyvében szintén említi Popovič ekvivalencia felfogását, amikor azt mutatja be, hogy milyen az egyes kutatók hozzáállása ehhez a bonyolult kérdéshez a fordítástudomány fejlődése során. Klaudy K. hangsúlyozza, hogy Popovič az ekvivalencia problémakörét a fordítás olvasója szempontjából vizsgálta, és nem a fordító szempontjából indult ki ennek a kérdésnek a megítélésénél. Egyúttal megjegyzi Popovičcsal kapcsolatban azt is, hogy azokhoz tartozott, akik ,nem úgy tekintettek az ekvivalenciára mint a fordítás általános előfeltételére, de megkísérelték körülírni az ekvivalencia különböző típusait” (Klaudy 2007: 81).

\section{Összefoglaló}

Anton Popovič már az első fontos könyvében 1961-ben, amely sajnos eddig nem jelent meg fordításban magyar vagy más nyelven, rámutatott az oroszmagyar irodalmi kontaktusokra, kiemelve elsősorban az orosz irodalom nagy hatását fordítások révén a szlovák irodalom fejlődésére a 19-ik század folyamán. Tágabb értelemben a történelmi Magyarország területén végbement orosz romantikus, realizmus előtti és realista müvek fogadtatásáról van itt szó a magyar és a szlovák olvasóközönség részéről a reformkortól a 19-ik század további évtizedein át. De ebben a könyvében még nem szemléltette a szerző ezeket az irodalom közötti kapcsolatokat konkrét müvek anyaga alapján az orosz-magyar, de az orosz-szlovák irodalmi kapcsolatok esetében sem. Könyvének utolsó mondata (vö. Popovič 1961: 137) azt a szerzői meggyőződést tartalmazza, hogy ezek a formálódó orosz realizmussal való kapcsolatok a reformkortól kezdve pozitív szerepet játszottak a realizmus stílusának megszületésénél a szlovák közegben, de arról, miként hatott az erös magyar realizmusra is a kapcsolattartás orosz irodalmi müvekkel, nem ejtett szót.

A 20-ik század már teljesen más fejezet a szerző munkásságában, hisz a legfontosabb könyvében már Popovič arra a megállapításra jutott, hogy éppen a gyenge gyökerekkel rendelkező szlovák szatirikus irodalomra volt mély hatással a szovjet szatíra egy kitünő szlovák átültetés által, amely közelebb vitte a fordítást az eredeti szöveghez annak ellenére, hogy az eredeti mü és az 1962-es szlovák fordítás között 30 éves időbeli és térbeli kulturális eltérés van, de Ján Ferenčík fordító az Ilf-Petrov kettőskönyvét kortárs írók müveként kezelte. Ez látható a szlovák fordításban a reáliákkal történő bánásmódon is. Erre a helyzetre Popovič következő megállapítása vonatkozik: „Az a hasonló társadalmi helyzet, amely a főhős létezését a két kultúrában (környezetben) lehetővé tette, több szemiotikailag ekvivalens szókészleti elem funkcionális 
cseréjét is megengedi. Így például a 'Старокомхоз' rövidítést 'Komunálny podnik'-nak (Közszolgálati Vállalat) fordítja“ (Popovič 1980: 171). A térbeli kulturális eltérés nem volt annyira érezhető a szlovák fordításon, mint a magyar háború végi átültetésben az akkori eltérő körülményekbe építve be a teljesen, homlokegyenest más világból lefordított könyvet. A háború vége felé még nem születhetett igazán olyan tipológiai és genetikai tulajdonságokkal rendelkező magyar fordítás, mert az olvasóknak nem voltak olyanok az élethelyzetei, mint az eredeti müben megírt élethelyzetek. Az orosz szövegben ábrázolt társadalmi helyzet szemiotikai azonosítása végbement az 1957-es nagy sikerü magyar fordításban, amikor már a fordítók ellentétben az előbbi fordítópárossal saját társadalmi tapasztalataik alapján dönthettek a szövegben lévő tematikai reáliák és nyelvi síkok tolmácsolása során. A fordítást nem fenyegette már az eredeti szöveg esztétikai értékeinek nyelvi és stilisztikai nivellálása sem, és ahogy azt a hasonló korszakban született szlovák átültetés is bizonyítja, olyan szöveg keletkezhetett, amely a szatirikus prózafejlődés társadalmi szempontjainak és igényeinek teljesen megfelelt.

\section{Irodalom}

Jankovics M. (2011) A fordítás elméletének és gyakorlatának orosz-magyar vonatkozásai. Szombathely.

Klaudy K. (2007) Languages in Translation. Lectures on the Theory, Teaching and Practice of Translation. Budapest.

Popovič, A. (1980) A müfordítás elmélete: A szöveg és az irodalmi metakommunikáció szempontjai. Bratislava.

Popovič, A. (1961) Ruská literatúra na Slovensku v rokoch 1863-1875. Bratislava.

Popovič, A. (1975) Teória umeleckého prekladu. Aspekty textu a literárnej metakomunikácie. Bratislava.

Tellinger, D. (2012) Der kulturelle Hintergrund des Translats - Kultur als Substanz der Kommunikation. Košice. 